\title{
The Determination of Nutrient Value, Digestibility and Energy Levels of Compound Feeds Used for Ruminant Nutrition by in Vitro Methods
}

\author{
Murat Sedat Baran ${ }^{1 *}$, Selçuk Altaçli², Oktay Kaplan', Suphi Deniz ${ }^{2}$ \\ ${ }^{I}$ Department of Animal Nutrition and Nutritional Diseases, Faculty of Veterinary Medicine, Dicle University, 21280 Diyarbaklr, Turkey \\ ${ }^{2}$ Department of Animal Nutrition and Nutritional Diseases, Faculty of Veterinary Medicine, Yüzüncü Yll University, 65090 Van, Turkey \\ A R T IC LE IN F O

\section{Research Article} \\ Received 15 March 2017 \\ Accepted 18 April 2017 \\ Keywords: \\ Compound feed \\ Energy content \\ In vitro digestibility \\ Nutrient \\ Ruminant \\ *Corresponding Author: \\ E-mail: msedatbaran@dicle.edu.tr \begin{abstract}
A B S T R A C T
There are small number of tables that show digestibility and energy contents of compound feeds produced by feed factory in different regions of Turkey. Thus, in this paper, four different compound feed types (dairy cattle, beef cattle, calf and lamb growing feeds), totalling 78 compound feeds were analysed to determine their feeding value, dry matter $(\mathrm{DM})$, organic matter $(\mathrm{OM})$ digestibility and energy content (digestible energy (DE), metabolisable energy (ME) and net energy for lactation (NEL). As a result of this study, the crude fiber (CF) levels were higher than standard values in calf and lamb compound feeds and beef cattle compound feeds; however, in the dairy cattle and calf and lamb compound feeds, the crude protein (CP) values were lower than standard values. These findings are considered highly important for the region's animal feeding. According to our results, the compound feeds for dairy cattle and lamb being used for ruminant nutrition in Diyarbakir Province of Turkey were found to have low nutrient qualities; however, in the calf feed both the metabolisable energy level and nutrient quantities were low.
\end{abstract}

DOI: https://doi.org/10.24925/turjaf.v5i7.832-835.1226

\section{Introduction}

To increase the healthful eating of animal products as an important part of our society, it is necessary to feed the animals in a rational way. In particular, the quantity and quality of proteins in animal feed are important. The feeding values and energy content of animal feeds vary according to, soil conditions, climate and processing methods etc. There are a small number tables that show digestibility and energy contents of compound feeds produced in different regions of Turkey. Low-quality feedstuffs can cause serious nutritional disorders in animals (Çelik et al., 2003; Ergün et al., 2004; Baran, 2014). In order to prevent health problems that arise from imbalanced and insufficient nutrition, it is essential to use a higher quality of animal products to manufacture feeds in animal nutrition (Akdeniz et al., 2005; Baran, 2014; Oğuz et al., 2016).

The nutrient content of feed materials used in compound feed production has been shown in the tables grouped in different sources (Dale and Batal 2005; Baran et al., 2008a). Baran et al. (2008b), working in the Diyarbakir province, studied the nutritional content of compound feeds for ruminants. Excluding beef cattle feed from the other compound feeds, they found that the feeds below the declared level of crude protein, while the crude fiber content was higher than declared.
There is a close relationship between the digestibility of feeds in terms of organic matter digestibility and energy (Turgut et al., 2002; Denek and Deniz 2004; Ergün et al., 2004). A fast and accurate method for determining the nutritional value of compound feed is of great importance. The determination of feed value is currently made through chemical and biological analyses. However, chemical analyses cannot adequately measure the real value of animal feeds; the actual feed quality depends on an evaluation of the nutrients in the context of the animals being fed (Kara and Deniz 2005). Classical digestion experiments used to determine the digestibility of feed are expensive and time consuming; the "in vitro two-stage digestion method" described by Tilley and Terry (1963) is currently used to determine the feed value of ruminant feeds. In this method, a feed sample is first rumen fluid is then determined digestibility by treatment with HCl-pepsin solution. In the first stage of the method, the crude fiber in the feed material is digested; in the second stage, insoluble proteins are degradated.

In light of the above information, in this study, the nutrient content of compound feeds commonly used in ruminant nutrition taken from the feed distributers in Diyarbakir Province of Turkey and assessed for digestibility and energy content using an in vitro method in order to compare the results with legal norms. 


\section{Materials and Methods}

In this study, 78 mixed feeds ( 21 dairy cattle, 21 beef cattle, 18 calf growing and 18 lamb growing feeds) were collected from in Diyarbakir Province of Turkey for use as materials. Samples of the feeds were collected from stores; classical sources were used for sample collection. When the samples reached the laboratory, their dry matter content was determined immediately (Meyer et al., 1983; Sarı and Çerçi 1993) and then the samples were stored at $20^{\circ} \mathrm{C}$. The ruminant feeds were analysed chemically according to the method of the Association of Official Analytical Chemists (2000); crude fiber was analysed according to Crampton and Maynard (1938). Digestible energy, metabolisable energy and net energy for lactation content of compound feed were calculated on the basis of the nutrient digestibility of the compound feed (Total digestible nutrients: TDN). For this purpose, the following equation was used (NRC 1989):

$$
\mathrm{DE}, \mathrm{Mcal} / \mathrm{kg} \mathrm{DM}=(\mathrm{TDN}) \% \times 0.04409 .
$$

$$
\begin{array}{ll}
\mathrm{ME}, \mathrm{Mcal} / \mathrm{kg} \mathrm{DM} & =\text { DE } \times 0.82 \\
\mathrm{NEL}, \mathrm{Mcal} / \mathrm{kg} \mathrm{DM} & =(\text { TDN } \% \times 0.0245)-0.12
\end{array}
$$

Dry matter (DM) and organic matter (OM) digestibility; two-stage digestion methods with each feed 3 to be sooner recurrence by Tilley and Terry (1963) reported and by Marten and Barnes (1980) was performed according to the modified method. For this purpose, feed samples in $39^{\circ} \mathrm{C}$ water bath before for $48 \mathrm{~h}$ was incubated with fresh rumen fluid. The samples were then treated with $0.2 \%$ pepsin- $\mathrm{HCl}$ solution for $24 \mathrm{~h}$ incubated. Used in this method rumen fluid, in dry matter requirement level (Altacli and Deniz, 2007), fed with meadow hay was taken from the coach rumen fistula.

The data in the tables are presented as means $(x) \pm$ standard deviation $(S x)$. In this study statistical evaluation of the data obtained analyses of variance were used (Steel and Torrie 1980).

\section{Results and Discussion}

In this study, the nutrient content of compound feeds (dairy cattle, beef cattle, calf and lamb growing feeds) used in ruminant nutrition taken from the warehouse in Diyarbakir Province of Turkey to determine the digestibility (DM and OM digestibility) and energy content (DE, ME, NEL) by an in vitro method and it aimed to compare them with legal norms.

From the point of view of nutrient content, there were no statistically significant differences amongst the feeds $(\mathrm{P}>0.05)$. The nutrient contents of the compound feeds used in this study are given in Table 1. The data in Table 1 were compared with data of domestic and foreign origins (NRC, 1989; TSI, 1991). The lamb, calf and dairy cattle feeds produced in Diyarbakir Province of Turkey had crude protein levels below standard values; in comparison, the dry matter, crude fat and crude ash contents were similar to standard values, whereas the crude fiber content in feed calf, lambs and beef cattle seems to be higher than the standard (NRC, 1989; Ensminger et al., 1990; TSI, 1991; Dale and Batal, 2005). In this case, growers higher prices and lower quality than that declared non-standard leads to buying feed. Except beef cattle feed, in other mixed feed; below the declared level of crude protein and the crude fiber content is on the declared are required farmers to be more selective while buying feed.

Baran et al. (2008b) conducted a study of the microbiological quality and nutrient content of compound feeds used in ruminant nutrition. They found that dairy cattle, beef cattle, calf and lamb feeds contained, on average, $14.39 \%, 10.13 \%, 11.13 \%$ and $14.05 \%$ crude protein, respectively, similar to our results. However, the crude fibre levels were $11.44 \%, 10.62 \%, 10.70 \%$ and $11.18 \%$, respectively, lower than the values found in our study. In a similar survey (Baran et al. 2008a), the crude protein values for dairy cattle feed were higher than in our findings at $15.13 \%$, while the crude protein level in beef cattle feeds was lower than our findings at $12.60 \%$. In the dairy and beef cattle feeds, the crude fiber content was $11.50 \%$ and $11.20 \%$, respectively, which is lower than that determined by our results.

The highest levels of crude ash were derived from the growing feed for lambs and calves, followed by the samples of dairy cattle feed. Previous studies (Baran et al., 2008a; 2008b) have produced similar results to ours in terms of the crude ash and nitrogen-free extract parameters for dairy cattle, beef cattle and calf and lamb enlargement feeds.

The DM and OM digestibility values of the compound feeds as determined by the two-stage digestion method in this study are given in Table 2. The highest DM and OM digestibility values as determined by the two-stage digestion method were obtained for the calf and lamb growing feeds. The lowest values of these parameters were obtained for beef cattle feeds. In a study by Denek and Deniz (2004), feed ingredients (other than oats) were found to be similar in terms of in vivo and in vitro DM and OM digestibility.

The DE, ME and NEL values of the compound feeds used in this study are given in Table 3. The energy content of a feed material (DE, ME and NEL) is obtained by multiplying by a certain coefficient of digestible nutrients; thus, there is a positive correlation between the amount of digestible nutrients and the energy value of the feed (Turgut et al., 2002; Denek and Deniz, 2004; Ergün et al., 2004). Indeed, when the digestibility of each compound feed was analysed (Table 2), the DM and OM digestibility and energy (DE, ME and NEL) values of the calf and lamb growing feeds seemed to be higher than those for the dairy and beef feeds.

Baran et al. (2008a) found that a large part of the nutritional value and quality of feedstuffs used in ruminant rations were lower than the standard. Therefore, feed values obtained from foreign sources used in rations in South-eastern Anatolia region can cause large errors in ruminant nutrition. 
Table 1 The nutrient contents of compound feeds, $\%$

\begin{tabular}{|c|c|c|c|c|c|c|c|c|c|c|c|c|c|}
\hline \multirow[t]{2}{*}{ Compound feeds } & \multicolumn{3}{|c|}{$\begin{array}{c}\text { Dry } \\
\text { matter }\end{array}$} & \multicolumn{2}{|c|}{$\begin{array}{l}\text { Crude } \\
\text { ash }\end{array}$} & \multicolumn{2}{|c|}{$\begin{array}{l}\text { Crude } \\
\text { protein }\end{array}$} & \multicolumn{2}{|c|}{$\begin{array}{l}\text { Crude } \\
\text { fat }\end{array}$} & \multicolumn{2}{|c|}{$\begin{array}{l}\text { Crude } \\
\text { fiber }\end{array}$} & \multicolumn{2}{|c|}{$\begin{array}{l}\text { Nitrogen-free } \\
\text { extract matter }\end{array}$} \\
\hline & $\mathrm{N}$ & $\mathrm{X}$ & $\mathrm{Sx}$ & $\mathrm{X}$ & $\mathrm{Sx}$ & $\mathrm{x}$ & Sx & $\mathrm{x}$ & $\mathrm{Sx}$ & $\mathrm{x}$ & $\mathrm{Sx}$ & $\mathrm{X}$ & $\mathrm{Sx}$ \\
\hline Dairy cattle feed & 21 & 92.74 & 0.13 & 8.37 & 0.56 & 14.81 & 0.54 & 2.43 & 0.13 & 14.10 & 1.34 & 53.56 & 1.69 \\
\hline Beef cattle feed & 21 & 92.40 & 0.17 & 8.31 & 0.43 & 13.17 & 0.57 & 2.63 & 0.18 & 14.26 & 1.50 & 54.03 & 1.57 \\
\hline Calf growing feed & 18 & 92.72 & 0.12 & 8.91 & 0.37 & 13.42 & 0.47 & 2.76 & 0.13 & 11.47 & 0.81 & 56.16 & 1.03 \\
\hline Lamb growing feed & 18 & 92.61 & 0.19 & 9.76 & 0.89 & 13.81 & 0.75 & 2.50 & 0.23 & 13.45 & 1.75 & 53.09 & 1.86 \\
\hline
\end{tabular}

Table 2 The dry matter and organic matter digestibility of compound feeds, $\%$

\begin{tabular}{|c|c|c|c|c|c|c|c|c|c|c|c|c|}
\hline \multirow[t]{2}{*}{ Nutrient digestibility } & \multicolumn{3}{|c|}{$\begin{array}{c}\text { Dairy cattle } \\
\text { feed }\end{array}$} & \multicolumn{3}{|c|}{$\begin{array}{l}\text { Beef cattle } \\
\text { feed }\end{array}$} & \multicolumn{3}{|c|}{$\begin{array}{c}\text { Calf growing } \\
\text { feed }\end{array}$} & \multicolumn{3}{|c|}{$\begin{array}{l}\text { Lamb growing } \\
\text { feed }\end{array}$} \\
\hline & $\mathrm{N}$ & $\mathrm{X}$ & $\mathrm{Sx}$ & $\mathrm{N}$ & $\mathrm{X}$ & $\mathrm{Sx}$ & $\mathrm{N}$ & $\mathrm{X}$ & Sx & $\mathrm{N}$ & $\mathrm{x}$ & $\mathrm{Sx}$ \\
\hline Dry matter & 21 & 66.28 & 1.14 & 21 & 65.46 & 0.92 & 18 & 68.50 & 0.85 & 18 & 66.89 & 1.56 \\
\hline Organic matter & 21 & 74.02 & 1.26 & 21 & 73.14 & 1.06 & 18 & 77.35 & 0.94 & 18 & 74.59 & 1.84 \\
\hline
\end{tabular}

Table 3 DE, ME and NEL values of compound feeds, Mcal/kg DM

\begin{tabular}{|c|c|c|c|c|c|c|c|c|c|c|c|c|}
\hline \multirow{2}{*}{ Energy contents } & \multicolumn{3}{|c|}{ Dairy cattle feed } & \multicolumn{3}{|c|}{ Beef cattle feed } & \multicolumn{3}{|c|}{ Calf growing feed } & \multicolumn{3}{|c|}{ Lamb growing feed } \\
\hline & $\mathrm{N}$ & $\mathrm{x}$ & $\mathrm{Sx}$ & $\mathrm{N}$ & $\mathrm{x}$ & $\mathrm{Sx}$ & $\mathrm{N}$ & $\mathrm{x}$ & $\mathrm{Sx}$ & $\mathrm{N}$ & $\mathrm{x}$ & $\mathrm{Sx}$ \\
\hline $\mathrm{DE}$ & 21 & 3.26 & 0.06 & 21 & 3.22 & 0.05 & 18 & 3.41 & 0.04 & 18 & 3.29 & 0.08 \\
\hline $\mathrm{ME}$ & 21 & 2.67 & 0.05 & 21 & 2.64 & 0.04 & 18 & 2.80 & 0.03 & 18 & 2.70 & 0.07 \\
\hline NEL & 21 & 1.69 & 0.03 & 21 & 1.67 & 0.03 & 18 & 1.78 & 0.02 & 18 & 1.71 & 0.05 \\
\hline
\end{tabular}

Compound feed standards are set by the Turkish Standards Institute (1991) and are used to assess the quality of compound feeds produced in Turkey. Based on the compound feeds examined in this study, a large number of feeds used in Diyarbakir Province of Turkey are of second-class quality compared with the standards of the Turkish Standards Institute. The new No. 5996, Veterinary Services, Plant Health, Food and Feed Law, entered into force on 13 December 2010. Under this law, the Feed Hygiene Regulation was issued in 2011 (İpçak and Alçiçek, 2013; Çetinkaya and Selçuk, 2015; Küçükersan and Küçükersan, 2015). In our country a better quality compound feed can be produced by implementation of the Feed Hygiene Regulation.

\section{Conclusions}

In dairy cattle with lamb and calf growing feeds to be lower than the standard (NRC, 1989; Ensminger et al., 1990; TSI, 1991; Dale and Batal, 2005) of nutrients is very important in terms of region animal husbandry. The determination of nutrients alone is not sufficient to assess the quality of feeds used for animal nutrition; also determining the digestibility and energy content is required. Use of the two-stage digestion method to determine the digestibility of compound feeds is expected to provide economic benefits to our country and region. In addition, implementation of the hazard analysis critical control point programme in the feed industry will ensure food safety from farm to table and enable farmers to obtain high-quality compound feed.

\section{References}

Akdeniz RC, Ak İ, Boyar S. 2005. Türkiye'de karma yem endüstrisi ve sorunları. VI. Türkiye Ziraat Mühendisliği Teknik Kongresi. TMMOB, Ankara, 935-959.
Altacli S, Deniz S. 2007. Değişik şekillerde hazırlanan yaş şeker pancarı posası silajlarının in vivo ve in vitro sindirilebilirlikleri ile enerji içeriklerinin belirlenmesi. IV. Ulusal Hayvan Besleme Kongresi. Bursa, s. 393-397.

AOAC (Association of Official Analytical Chemists). 2000. Official Methods of Analysis, 17th ed. Maryland, USA.

Baran MS, Demirel R, Şentürk Demirel D, Şahin T, Yeşilbağ D. 2008a. Determination of the feeding values of feedstuffs and mixed feeds used in the Southeastern Anatolia Region of Turkey. Turkish Journal of Veterinary and Animal Sciences, 32: 449-455.

Baran MS, Erkan ME, Vural A. 2008b. Diyarbakır yöresinde ruminant beslenmesinde kullanılan karma yemlerin besin madde ve mikrobiyolojik kalite özellikleri. İstanbul Üniversitesi Veteriner Fakültesi Dergisi, 34: 9-19.

Baran MS. 2014. Yemler Yem Hijyeni ve Teknolojisi. Dicle Üniv. Vet. Fak. Ders Kitabı. Diyarbakır.

Crampton EW, Maynard LA. 1938. The relation of cellulose and lignin content to the nutritive value of animal feeds. Journal Nutrition, 15: 383-395.

Çelik K, Ertürk MM, Ersoy İE. 2003. Farklı yem fabrikalarından örneklenen karma yem ve yem ham maddelerinde bazı kalite öğelerinin kantitatif araştırılması. Akdeniz Üniversitesi Ziraat Fakültesi Dergisi, 16: 161-168.

Çetinkaya N, Selçuk Z. 2015. Yem güvenliği mevzuatı ve yem güvenirliği yönetim sistemi. Turkiye Klinikleri, Journal Animal Nutrition and Nutritional Diseases-Special Topics, 1(1): 1-7.

Dale N, Batal A. 2005. Feedstuffs Reference Issue and Buyers Guide. 76: 16-22.

Denek N, Deniz S. 2004. Ruminant beslenmesinde kullanılan bazı dane yemlerin enerji düzeylerinin in vivo ve in vitro metotlarla belirlenmesi. Turkish Journal of Veterinary and Animal Sciences, 28: 185-193.

Ensminger, ME, Oldfield, JE, Heinemann, WW. 1990. Feeds and Nutrition. 2nd Ed., The Ensminger Publishing Company. Clovis, California.

Ergün A, Tuncer ŞD, Çolpan İ, Yalçın S, Yıldız G, Küçükersan KM, Küçükersan S, Şehu A. 2004. Yem Hijyeni ve Teknolojisi. Ankara Üniversitesi Veteriner Fakültesi Ders Kitab1, Ankara.

İpçak HH, Alçiçek A. 2013. Yeni yem kanunu ve yem hijyen yönetmeliği çerçevesinde yemlerde mikotoksin problemi ve çözüm önerileri. VII. Ulusal Hayvan Besleme Kongresi, Ankara, 343- 348. 
Kara MA, Deniz S. 2005. Van yöresinde üretilen kuru otların besin madde içeriği ile sindirilebilirlik ve enerji içeriklerinin in vitro ve in sacco yöntemlerle belirlenmesi. III. Ulusal Hayvan Besleme Kongresi, Adana, s. 505-511.

Küçükersan S, Küçükersan KM. 2015. Yemlerde biyogüvenlik ve hayvan sağlığı ilişkisi. Türkiye Klinikleri, Journal Animal Nutrition and Nutritional Diseases-Special Topics, 1(1): 8-18.

Marten, GC, Barnes, RF. 1980. Prediction of energy digestibility of forages with in vitro rumen fermentation and fungal enzyme systems. In Proc. Int. Workshop on Standardization of Analytical Methodology for Feed. Ed. Pigden, WJ, Balch, CC, Graham, M, Int. Dev. Res. Center, Ottawa, Canada.

Meyer H, Bronsch K, Leibetseder J. 1983. Suplemente zu Volesungen und Ubungen in der Tierernaehrung. Verlag Sprungmann, Hannover.

NRC: Nutrient Requirements of Dairy Cattle. 1989. 6 th Revised Ed. National Academy Press, Washington D. C, USA.
Oğuz Karakaş F, Buğdaycı KE, Gümüş H, Oğuz MN. 2016. Hayvansal ürünlerin raf ömrünü artırmada hayvan beslemenin önemi. Turkiye Klinikleri, Journal Animal Nutrition and Nutritional Diseases-Special Topics, 2(3): 36-44.

Sarı M, Çerçi İH. 1993. Yemler, Hayvan Besleme ve Beslenme Hastalıkları. Fırat Üniversitesi Veteriner Fakültesi, Elazığ.

Steel RCD, Torrie JH. 1980. Principles and procedures of statistics. A biometrical approach. 2nd ed. Mc Graw- Hill Book Company, New York.

Tilley JMA, Terry RA. 1963. A Two-Stage Tecnique for In Vitro Digestion of Forage. J Br Grassl Soc, 18: 104-111.

Turgut L, Yanar M, Aksoy A. 2002. Baz1 enerji yemlerinin in situ tekniği ile kuru madde ve organik madde parçalanabilirliklerinin belirlenmesi. Atatürk Üniversitesi Ziraat Fakültesi Dergisi, 33: 435-440.

Turkish Standard Institute (TSI). 1991. Animal Feeds-Metabolic Energy Determination (Chemical Method). TSI No: 9610, Ankara. 